\title{
Penerapan Metode Pembelajaran Picture and Picture untuk Meningkatkan Hasil Belajar Geografi Kelas XI IIS 1 SMA Negeri I Koto Besar Dharmasraya
}

\section{Ermita}

SMA Negeri I Koto Besar Dharmasraya, Indonesia

email : ermitakotobesar@gmail.com

\begin{abstract}
This study aims to develop lokal wisdom in teaching materials without having to eliminate the substance of the material that is the goal of the curriculum. The method used in this study is the Research and Development Model 4 D method, namely Define, design, development and dissemination. meanwhile, the instruments or data collection tools are documentation and validation questionnaire for the feasibility of the companion book that was developed. The results of this study are the compilation of 8 companion books for thematic learning based on lokal wisdom in the West Kalimantan area for Class III, with 4 assessment aspects which include assessment of content aspects the average aspect of the assessment is 4.68 equivalent to $93.75 \%$ (Valid / Eligible to use), feasibility aspects the presentation of subject matter in accordance with the 2018 ministry of national education thematic learning book, an average assessment of 4.76 is equivalent to $95 \%$ (Valid/Eligible to use). the feasibility aspect of book design display on the development of lokal wisdom-based teaching materials obtained an average value of 4.8 equivalent to $96.7 \%$ (Valid / Eligible to use), the feasibility aspect of the language used in the development of lokal wisdom-based teaching materials obtained an average value of 4.64 equivalent to $96.7 \%$ (Valid / eligible to use)
\end{abstract}

\section{Keywords: Development of Thematic Teaching Materials, and Lokal Wisdom}

\begin{abstract}
Abstrak: Penelitian ini bertujuan untuk mengembangkan kearifan lokal dalam bahan ajar tanpa harus menghilangkan substansi materi yang menjadi tujuan kurikulum. Adapun metode yang digunakan dalam penelitian ini adalah metode Research and Development Model 4 D yakni Define, Design, Development and Dissemination. Sedangkan instrumen atau alat pengumpulan datanya adalah, dokumentasi dan angket validasi untuk kelayakan buku pendamping yang dikembangkan. Hasil penelitian ini adalah tersusunnya 8 buah buku pendamping untuk pembelajaran tematik berbasis kearifan lokal daerah Kalimantan barat untuk Kelas III, dengan 4 aspek penilaian yang meliputi penilaian terhadap aspek isi materi rata aspek penilaiannya 4.68 setara dengan $93.75 \%$ (Valid/ Layak digunakan), aspek kelayakan penyajian materi pelajaran yang sesuai dengan buku pembelajaran tematik kemendiknas tahun 2018 rata-rata penilaian 4.76 setara dengan $95 \%$ ( Valid/Layak untuk digunakan). aspek kelayakan tampilan desain buku pada pengembangan bahan ajar berbasis kearifan lokal diperoleh nilai ratarata 4.8 setara dengan $96.7 \%$ (Valid/ Layak untuk digunakan), aspek kelayakan bahasa yang digunakan pada pengembangan bahan ajar berbasis kearifan lokal diperoleh nilai rata-rata 4.64 setara dengan $96.7 \%$ (Valid / layak untuk digunakan).
\end{abstract}

Kata Kunci: Pengembangan Bahan Ajar Tematik, dan Kearifan Lokal 


\section{PENDAHULUAN}

Peran teknologi dan ilmu pengetahuan telah menyentuh segala aspek pendidikan sehingga informasi lebih mudah di peroleh, hendaknya menjadikan anak lebih aktif berpartisipasi sehingga melibatkan intelektual dan emosional siswa dalam proses belajar. Keberhasilan tujuan pendidikan terutama di tentukan oleh proses belajar mengajar yang di alami oleh siswa. Kemuan belajar yang kuat, dapat mendorong perubahan siswa pada aspek pengetahuan, pemahaman, penalaran, keterampilan, nilai dan sikap (Emda, 2018). Agar perubahan tersebut dapat tercapai dengan baik, maka diperlukan berbagai faktor untuk menghasilkan perubahan yang diharapkan yaitu penguasaan pemahaman konsep.

Oleh karena itu pendidik dituntut mampu menerapkan model pembelajaran inovatif untuk meningkatkan aktifitas dan hasil belajar siswa (Prihatiningsih \& Setyanigtyas, 2018). Pendidik profesional sangat berpengaruh secara signifikan dalam membantu siswa mengembangkan potensi yang dimiliki dengan melaksanakan pembelajaran yang efektif dan efisien (Ayuni, 2016). Sehingga peserta didik sebagai subjek pembelajaran dapat terlayani dengan baik dalam proses pencapaian kompetensi yang telah ditentukan.

Geografi sebagai cabang ilmu pengetahuan alam mempunyai peranan yang sangat penting dalam perkembangan teknologi di masa depan. Menurut Kresnawati (2013) pembelajaran geografi diharapkan mampu berperan dalam pembentukan sikap positif siswa yang berimplikasi pada pembentukan karakter yang matang. Dalam proses pembelajaran diperlukan penetapan tujuan yang komprehensif meliputi, pengembangan potensi pada aspek kognitif, afektif maupun psikomotorik. Untuk mencapai tujuan pembelajaran diperlukan perencanaan pembelajaran yang baik sebagai salah satu faktor penentu keberhasilan kegiatan pembelajaran yang optimal (Khalim \& Oktapian, 2020).

Namun beberapa permasalah dalam pembelajaran masih sering ditemukan. Seiring dengan aspek pendidikan di Indonesia yang terus mengalami perkembangan kuantitatif. Dibuktikan dengan jumlah sekolah makin bertambah dan jumlah siswa sekolah juga bertambah. Demikian pula daya serap sekolah terhadap anak usia sekolah makin meningkat. Ini semua menunjukkan adanya perkembangan kuantitatif yang semakin baik. Namun perkembangan ini belum diimbangi dengan perkembangan secara kualitatif. Kualitas lulusan di hampir semua jenjang 
pendidikan belum baku menunjukkan mutu seperti yang diharapkan. Hal ini banyak disebabkan oleh rendahnya tingkat ketuntasan siswa dan kemampuan siswa dalam memahami materi dengan baik. Dalam proses pembelajaran ditemukan beberap faktor yang mempengaruhi hal tersebut yaitu: 1) motivasi belajar siswa rendah. 2) metode pembelajaran yang kurang tepat, 3) pemanfaat media pembelajaran yang masih minim, 4) situasi lingkungan sekitar.

Berdasarkan permasalahan tersebut dibutuhkan implementasi metode pembelajaran yang sesuai untuk mencapati tujuan pembalajaran. Salah satu metode yang dapat diterapkan adalah pembelajaran Picture and Picture. Metode pemebelajaran Picture and Picture dilaksanakan dengan menggunakan gambar yang dipasangkan atau diurutkan menjadi urutan yang logis (Gaffar, 2018). Dalam pelaksanaannya metode Picture and Picture dapat membantu siswa menyamakan persepsi tentang gambar yang dihadirkan, sehingga setiap anggota kelompok mempunyai tujuan yang sama.

Menurut Kurniasih ( dalam Gumay \& Ali, 2019) langkah-langkah model Picture And Picture adalah sebagai berikut:

1. Guru menyampaikan tujuan pembelajaran yang ingin dicapai

2. Guru menyampaikan pengantar pembelajaran,

3. Guru memperlihatkan gambar-gambar yang telah disiapkan

4. Siswa dipanggil secara bergantian untuk mengurutkan gambar menjadi urutan logis

5. Guru menanyakan alasan logis urutan gambar, setelah gambar menjadi/guru harus bisa menanamkan konsep atau materi sesuai dengan kompetensi yang ingin dicapai

Kelebihan dari model picture and picture melatih siswa untuk berpikir logis dan sistematis. Membantu siswa belajar berpikir berdasarkan sudut pandang suatu subjek bahasan dengan memberikan kebebasan siswa beragumen terhadap gambar yang diperlihatkan. Selain itu, dapat memunculkan motivasi belajar siswa kearah yang lebih baik

Berdasarkan latar belakang diatas penulis berusaha melakukan penelitian tindakan kelas dengan judul Penerapan Metode Pembelajaran Picture And Picture untuk Meningkatkan Hasil Belajar Geografi Kelas Xi Iis 1 SMA Negeri I Koto 
Besar Dharmasraya. Penelitian ini bertujuan untuk mengetahui peningkatan hasil belajar siswa melalui penerapan model pembelajaran Picture And Picture .

\section{METODE PENELITIAN}

Jenis penelitian ini adalah Penelitian Tindakan Kelas (PTK) model Kemis dan Mc.Taggart. Penelitian ini dilakukan secara kolaboratif antara guru SMA Negeri 1 Koto Besar dengan peneliti. Guru bertindak sebagai pelaksana pembelajaran, sedangkan peneliti bertindak sebagai observer. Penelitian ini dilaksakan di kelas XI IIS 1 SMA Negeri I Koto Besar Dharmasraya. Subjek dalam penelitian ini adalah siswa kelas XI IIS 1 yang berjumlah 14 siswa, terdiri atas perempuan 5 orang dan laki-laki 9 orang siswa. Dari jumlah tersebut memiliki latar belakang pendidikan orang tua siswa, prestasi akademik, status Geografi yang heterogen. Dilihat dari asalnya, data dibedakan menjadi data primer dan data sekunder. Teknik pengumpulan data mengunakan metode observasi dan dokumentasi. Data yang dikumpulkan adalah dokumen catatan individu siswa untuk data hasil belajar kondisi awal, dokumen catatan individu siswa untuk data hasil belajar siklus I dan dokumen catatan individu siswa untuk data hasil belajar siklus II.

Data penggunaan metode pembelajaran Picture And Picture yang diperoleh melalui pengamatan agar diperoleh data yang valid, divalidasi dengan bantuan kolaboratorasi dengan teman sejawat yang bertindak sebagai kolaboratorator, selain itu juga data dari siswa (triangulasi sumber antara peneliti, kolaborator, dan siswa). Data hasil belajar Geografi agar valid perlu dibuatkan kisi-kisi sebelum soal disusun. Validasi ini dilakukan terhadap instrumen penilaian tes tertulis berupa penyusunan kisi-kisi sehingga terpenuhi validitas cakupan materi.

Analisis data menggunakan deskripsi komperatif yang diteruskan dengan refleksi. Deskripsi komperatif dilakukan dengan membandingkan data kondisi awal, siklus I, dan siklus II, untuk hasil belajar siswa. Kemudian dilakukan refleksi untuk menarik kesimpulan berdasarkan deskriptif komperatif dan dilanjutkan memberikan ulasan dan langkah-langkah tindak lanjut. Data hasil belajar siswa, diperoleh dengan ujian Harian setelah selesai persiklus. Setelah data dikumpulkan, hasil belajar siswa dihitung dengan menggunakan rumus rata-rata.

Indikator keberhasilan direfleksikan sebagai berikut: 1) Pencapai rata-rata kelas hasil belajar Geografi $>$ atau $=78,00$ (kualifikasi baik) pada siklus I, 
mencapai rata-rata hasil belajar Geografi 78,00 ( kualifikasi baik ) pada siklus II mencapai rata-rata hasil belajar Geografi 78,00 ( kualifikasi baik ) 2) siswa memperoleh nilai hasil belajar $>$ atau $=78$ dikatakan baik. Pada siklus I, dan II. Nilai 78 merupakan nilai ketuntasan minimal ( KKM ) mata pelajaran.

Prosedur penelitian ini diawali dengan perencanaan tindakan ( planning ) diteruskan dengan pelaksanaan tindakan (action) setelah itu diikuti dengan pengamatan sistematik terhadap tindakan dan akibat yang akan ditimbulkan (observasi). Refleksi dari hasil pengamatan tersebut. Kemudian diulang i lagi dengan perencanaan tindakan berikutnya dan sampai refleksi lagi. Pelaksanaan tindakan dalam penelitian ini mencakup empat kegiatan yaitu, perencanaan, pelaksanaan, pengamatan dan refleksi, yang merupakan satu kesatuan yang tidak bisa dipisahkan.

\section{HASIL DAN PEMBAHASAN}

\section{Hasil}

\section{Deskripsi Kondisi Awal}

\section{Hasil Belajar Geografi}

Dalam kegiatan belajar mengajar maupun dalam penugasan, siswa cenderung pasif kurang termotivasi di dalam belajar. Hal ini ditandai dengan banyaknya siswa yang tidak mengerjakan tugas dengan dalih mereka mengatakan tidak bisa, tidak memahami apa yang diterangkan oleh guru, ada juga sebagian siswa yang mengantuk, mengobrol dengan teman yang duduk di sampingnya atau bahkan yang ada di depan atau di belakang tempat duduknya. Demikian juga bila pembelajar dilakukan dengan diskusi mereka cenderung diam, pasif, dan tidak mau berpikir sama sekali.

Pada kondisi awal hasil belajar siswa diambil pada saat pembelajaran sebelum dilakukan tindakan. Pengamatan dilakukan pada saat guru menyampaikan pembelajaran denga $\mathrm{n}$ menggunakan metode mengajar ceramah dan sesekali diselingi dengan diskusi secara klasikal pada materi menyusun sikus akuntansi perusahaan dagang. Berikut hasil belajar Geografi pada pra siklus tersaji dalam tabel berikut. 
Tabel 1 : Hasil belajar siswa kondisi awal (Pra-Siklus)

\begin{tabular}{clcl}
\hline No & \multicolumn{1}{c}{ Nama } & Nilai & Ketuntasan \\
\hline 1 & Afdal & 75 & Tidak Tuntas \\
\hline 2 & Aldiansyah & 75 & Tidak Tuntas \\
\hline 3 & Anisa & 75 & Tidak Tuntas \\
\hline 4 & Bregi Saputra & 75 & Tidak Tuntas \\
\hline 5 & Gustina & 80 & Tuntas \\
\hline 6 & Indah linggo Geni & 70 & Tidak Tuntas \\
\hline 7 & Fauzan & 60 & Tidak Tuntas \\
\hline 8 & Loli Gustina & 60 & Tidak Tuntas \\
\hline 9 & Ogim Junaidi & 70 & Tidak Tuntas \\
\hline 10 & Sonya Senja A & 70 & Tidak Tuntas \\
\hline 11 & Tomi Sugara & 70 & Tidak Tuntas \\
\hline 12 & Tori Afrianto & 70 & Tidak Tuntas \\
\hline 13 & Ilman Febriandi & 80 & Tuntas \\
\hline 14 & Rahmat Hidayat & 80 & Tuntas \\
\hline & Jumlah & $\mathbf{1 0 1 0}$ & \\
\hline & Rata-rata Kelas & $\mathbf{7 2}$ & \\
\hline
\end{tabular}

Berdasarkan Table 1 Rata-rata hasil belajar siswa kelas XI IIS 1 adalah sebesar 72, dan belum mencapai KKM sebesar 78 . Dari hasil tersebut dapat diartikan pemahaman siswa terhadap materi masih belum mencapai KKM. Penyebabnya adalah kurangnya semangat siswa dalam belajar ditandai oleh kurang antusias siswa pada saat mengikuti pembelajaran, seperti kurangnya keinginan siswa untuk bertanya atau memberi tanggapan pada saat mengikuti pembelajaran. Demikian juga berdasarkan pengamatan konsentrasi siswa kurang dalam mengikuti pembelajaran. Pada saat guru menjelaskan materi pelajaran masih dijumpai siswa yang kurang memerhatikan, mereka berbincang-bincang sendiri dengan teman yang ada di sampingnya atau bahkan yang ada di belakang maupun yang ada di depan tempat duduknya. Hal ini mengindikasikan bahwa hasil belajar siswa masih rendah.

\section{Diskripsi Hasil Siklus I}

Tindakan yang dilakukan meliputi

1. Perencanaan

Peneliti menyusun rencana pelaksanaan pembelajaran dengan melengkapi instrumen penilaian dan lembar pengamatan.

2. Pelaksanaan Tindakan 
Penelitian tindakan kelas pada siklus pertama ini terdiri dari dua pertemuan, dengan langkah sebagai berikut:

a. Apersepsi

Guru mempersiapkan belajar siswa dengan berdoa dan mengabsen siswa.

Guru memberikan pertanyaan awal tentang kurva permintaan investasi.

Menjelaskan cakupan materi.

b. Kegiatan Inti

1. Eksplorasi

a) Guru menyajikan infomasi sebagai pengantar ke materi pembelajaran dengan infokus,

b) Dilanjutkan mengorganisasikan siswa dalam pemberian latihanlatihan.

2. Elaborasi

a) Guru memberikan latihan secara indifidu yang harus dikerjakan secara individu.

b) Mempresentasikan secara bergiliran perindifidu kedepan kelas.

c) Guru berkeliling untuk mengecek pemahaman siswa, mengamati jalannya kegiatan yang dilakukan oleh siswa dalam melaksanakan latihan dan memberikan bantuan kepada siswa yang mengalami kesulitan sambil melaksanakan penilaian proses, yaitu penilaian kinerja kognitif, afektif, dan psikomotorik.

d) Kolaborator mengamati kegiatan guru dan siswa selama proses pembelajaran dengan menggunakan instrumen pengamatan yang telah dipersiapkan sebelumnya.

\section{Konfirmasi}

a) Guru memberikan umpan balik positif secara lisan maupun tulisan terhadap keberhasilan siswa dalam mengikuti pembelajaran.

b) Guru memberikan konfirmasi terhadap hasil eksplorasi dan elaborasi.

c) Guru memfasilitasi siswa untuk memperoleh pengalaman belajar yang bernakna dalam mencapai kompetensi dasar dengan memberikan informasi untuk berekplorasi lebih jauh. 
4. Penutup

a) Guru memberikan penghargaan kepada siswa yang mampu mengerjakan latihan dengan bagus.

b) Guru bersama-sama dengan siswa membuat rangkuman / simpulan pelajaran.

c) Guru memberikan materi untuk minggu depan.

d) Gurru menutup pelajaran dengan mengucapkan salam.

e) Siswa menjawab salam guru.

3. Hasil Pengamatan

Pada siklus I pembelajaran sudah menggunakan Model Pembelajaran Picture And Picture pada Data siklus pertama terdiri dua pertemuan, pertemuan pertama adalah mengidentifikasi pengaruh faktor geografis terhadap keragaman budaya di Indonesia, menganalisis persebaran keragaman budaya di Indonesia, dan menganalisis pembentukan kebudayaan nasional. Sementara pada pertemuan ke 2 adalah menganalisis pelestarian dan pemanfaatan produk kebudayaan Indonesia dalam bidang Geografi kreatif dan pariwisata serta menerapkan kebudayaan Indonesia sebagai bagian dari kebudayaan global. Pembelajaran berjalan kurang lancar karena masih banyak siswa yang kurang termotivasi dalam belajar Geografi karena banyak siswa yang tidak ikut serta memberikan tanggapan maupun mengajukan pertanyaan. Pada saat mengerjakan latihan masih banyak siswa yang belum melaksanakan tugas dengan baik, mereka cenderung diam melihat temannya yang terlihat sungguh-sungguh dalam mengerjakan tugas. Berikut hasil belajar siswa pada siklus I.

Tabel 2 Hasil Belajar Siswa siklus I

\begin{tabular}{clcc}
\hline No & \multicolumn{1}{c}{ Nama } & Nilai & Ketuntasan \\
\hline 1 & Afdal & 80 & Tuntas \\
\hline 2 & Aldiansyah & 80 & Tuntas \\
\hline 3 & Anisa & 85 & Tuntas \\
\hline 4 & Bregi Saputra & 80 & Tuntas \\
\hline 5 & Gustina & 80 & Tuntas \\
\hline 6 & Indah linggo Geni & 75 & Tidak Tuntas \\
\hline 7 & Fauzan & 80 & Tuntas \\
\hline 8 & Loli Gustina & 65 & Tidak Tuntas \\
\hline 9 & Ogim Junaidi & 60 & Tuntas \\
\hline
\end{tabular}




\begin{tabular}{llcc}
\hline 10 & Sonya Senja A & 80 & Tuntas \\
\hline 11 & Tomi Sugara & 80 & Tuntas \\
\hline 12 & Tori Afrianto & 80 & Tuntas \\
\hline 13 & Ilman Febriandi & 70 & Tidak Tuntas \\
\hline 14 & Rahmat Hidayat & 80 & Tuntas \\
\hline & Jumlah & $\mathbf{1 0 7 5}$ & \\
\hline & Rata-rata Kelas & $\mathbf{7 7}$ & \\
\hline
\end{tabular}

Berdasarkan Table diatas dapat diketahui hasil belajar Geografi siswa kelas XI IIS 1 SMA Negeri 1 Koto Besar Dharmasraya memiliki rata-rata rata-rata kelas 77. Dari hasil tersebut dapat dilihat bahwa hasil belajar siswa sudah meningkat dibandingkan dengan prasiklus, dari rata-rata 72 menjadi 77. Melihat kenaikan hasil belajar Geografi siswa kelas XI IIS 1 SMA Negeri I Koto Besar dengan menggunakan Model Pembelajaran Picture And Picture belum maksimal, sehingga perlu dilanjutkan pada siklus II .

Refleksi

Pada akhir siklus I tingkat hasil belajar geografi belum mencapai maksimal berdasarkan pengamatan kolaborator terdapat beberapa hal yang perlu perbaikan antara lain:

a. Guru belum optimal dalam membangkitkan motivasi siswa untuk mengikuti pembelajaran.

b. Guru kurang tegas dalam menyampaikan materi.

c. Siswa kurang memperhatikan guru pada saat guru menyimpulkan materi.

Karena itu perlu dilakukan perbaikan yang dapat meningkatkan hasil belajar siswa pada siklus II.

\section{Deskripsi siklus ke II}

\section{Perencanaan ( Planning )}

Guru menyusun rencana pelaksanaan pembelajaran atas dasar refleksi siklus pertama dengan 2 kali pertemuan, menyiapkan instrumen penelitian.

2. Pelaksanan Tindakan (Acting)

Penelitian tindakan kelas pada siklus kedua ini terdiri dari dua pertemuan, pertemuan pertama dilaksanakan pada hari Senin, tanggal 07 Mei 2018, 
pertemuan kedua hari Senin tanggal 14 Mei 2018, dengan langkah sebagai berikut:

a. Apersepsi

1) Guru menyiapkan kondisi kelas dengan berdoa bersama dan mengabsen kehadiran siswa.

2) Guru mengingatkan kembali tentang materi perbankan dengan melontarkan beberapa pertanyaan.

3) Guru memotivasi siswa dengan menyampaikan pertanyaan awal tentang Membedakan peran bank umum dan bank sentral.

b. Kegiatan Inti

1. Eksplorasi

a) Guru menyajikan infomasi sebagai pengantar ke materi pembelajaran dengan infokus,

b) Dilanjutkan mengorganisasikan siswa dalam pemberian latihanlatihan.

2. Elaborasi

a) Guru memberikan latihan secara individu yang harus dikerjakan secara individu.

b) Mempresentasikan secara bergiliran perindividu kedepan kelas.

c) Guru berkeliling untuk mengecek pemahaman siswa, mengamati jalannya kegiatan yang dilakukan oleh siswa dalam melaksanakan latihan dan memberikan bantuan kepada siswa yang mengalami kesulitan sambil melaksanakan penilaian proses, yaitu penilaian kinerja kognitif, afektif, dan psikomotorik.

d) Kolaborator mengamati kegiatan guru dan siswa selama proses pembelajaran dengan menggunakan instrumen pengamatan yang telah dipersiapkan sebelumnya.

\section{Konfirmasi}

a) Guru memberikan umpan balik positif secara lisan maupun tulisan terhadap keberhasilan siswa dalam mengikuti pembelajaran.

b) Guru memberikan konfirmasi terhadap hasil eksplorasi dan elaborasi. 
c) Guru memfasilitasi siswa untuk memperoleh pengalaman belajar yang bernakna dalam mencapai kompetensi dasar dengan memberikan informasi untuk berekplorasi lebih jauh.

\section{c. Penutup}

1) Guru memberikan penghargaan kepada siswa yang mampu mengerjakan latihan dengan bagus.

2) Guru bersama-sama dengan siswa membuat rangkuman / simpulan pelajaran.

3) Guru memberikan materi untuk minggu depan.

4) Gurru menutup pelajaran dengan mengucapkan salam.

5) Siswa menjawab salam guru.

\section{Hasil Pengamatan (Observing)}

Pada siklus II pembelajaran masih menggunakan Model Pembelajaran Picture And Picture pada siklus kedua terdiri dari dua pertemuan yaitu pertemuan pertama mendiskripsikan jenis dan karakteristik bencana alam, menganalisis siklus penanggulangan bencana dan menganalisi persebaran wilayah rawan bencana alam di Indonesia sedangkan pertemuan kedua adalah mengidentifikasi lembaga-lembaga yang berperan dalam penanggulangan bencana alam dan mengidentifikasi partisipasi masyarakat dalam mitigasi bencana alam di Indonesia. Pembelajaran berjalan sudah lumayan lancar, siswa sebagian mulai termotivasi dalam belajar Geografi terlihat banyak siswa mulai belajar mengerjakan latihan yang guru berikan.

Tabel 3. Hasil Belajar Siswa siklus II

\begin{tabular}{clcc}
\hline No & & Nilai & Ketuntasan \\
\hline 1 & Afdal & 80 & Tuntas \\
\hline 2 & Aldiansyah & 85 & Tuntas \\
\hline 3 & Anisa & 100 & Tuntas \\
\hline 4 & Bregi Saputra & 85 & Tuntas \\
\hline 5 & Gustina & 80 & Tuntas \\
\hline 6 & Indah linggo Geni & 90 & Tuntas \\
\hline 7 & Fauzan & 85 & Tuntas \\
\hline 8 & Loli Gustina & 70 & Tidak Tuntas \\
\hline
\end{tabular}




\begin{tabular}{clcl}
\hline 9 & Ogim Junaidi & 80 & Tuntas \\
\hline 10 & Sonya Senja A & 80 & Tuntas \\
\hline 11 & Tomi Sugara & 80 & Tuntas \\
\hline 12 & Tori Afrianto & 80 & Tuntas \\
\hline 13 & Ilman Febriandi & 85 & Tuntas \\
\hline 14 & Rahmat Hidayat & 85 & Tuntas \\
\hline & Jumlah & 1165 & \\
\hline & Rata-rata Kelas & 83,21 & \\
\hline & Pembulatan & 83 & \\
\hline
\end{tabular}

Berdasarkan Table diatas dapat diketahui bahwa hasil belajar Geografi siswa kelas XI IIS 1 Negeri 1 Koto Besar Dharmasraya memiliki rata-rata kelas 83. Berarti pada siklus II udah mengalami kenaikan dari rata-rata 77 menjadi 83. Jadi Upaya meningkatkan hasil belajar siswa kelas XI IIS 1 SMA Negeri I Koto Besar dengan menggunakan Model Pembelajaran Picture And Picture pada siklus II mengalami peningkatan maksimal dan tidak perlu dilakukan siklus ke III.

\section{Refleksi ( Reflecting )}

Pada akhir siklus II hasil belajar geografi sudah mencapai hasil maksimal berdasarkan pengamatan kolaborator. Dari uraian kegiatan pelaksanaan perbaikan pembelajaran melaui Dua siklus tersebut terlihat adanya perubahan yang menuju kesempurnaan, baik dari segi guru siswa dan perangkat pembelajaran sehingga hasil yang diperoleh memuaskan.

Dengan menggunakan Model Pembelajaran Picture And Picture ternyata tingkat hasil belajar siswa dalam belajar Geografi menunjukkan peningkatan dari kondisi awal memiliki rata-rata 72 , Sementara itu pada siklus I diperoleh rata-rata 77, dan pada siklus II terlihat naik rata-ratanya menjagi 83. Ini menunjukan hal yang bagus sesuai dengan yang diharapkan, sebagaimana pada tabel berikut:

Tabel 4 Table Perbandingan Per Siklus

\begin{tabular}{clccc}
\hline No & Nama & $\begin{array}{c}\text { Nilai } \\
\text { Pra Siklus }\end{array}$ & Nilai Siklus 1 & $\begin{array}{c}\text { Nilai } \\
\text { Silkus 2 }\end{array}$ \\
\hline 1 & Afdal & 75 & 80 & 80 \\
\hline 2 & Aldiansyah & 75 & 80 & 85 \\
\hline 3 & Anisa & 75 & 85 & 100 \\
\hline
\end{tabular}




\begin{tabular}{llccc}
\hline 4 & Bregi Saputra & 75 & 80 & 85 \\
\hline 5 & Gustina & 80 & 80 & 80 \\
\hline 6 & Indah linggo Geni & 70 & 75 & 90 \\
\hline 7 & Fauzan & 60 & 80 & 85 \\
\hline 8 & Loli Gustina & 60 & 65 & 70 \\
\hline 9 & Ogim Junaidi & 70 & 60 & 80 \\
\hline 10 & Sonya Senja A & 70 & 80 & 80 \\
\hline 11 & Tomi Sugara & 70 & 80 & 80 \\
\hline 12 & Tori Afrianto & 70 & 80 & 80 \\
\hline 13 & Ilman Febriandi & 80 & 70 & 85 \\
\hline 14 & Rahmat Hidayat & 80 & 80 & 85 \\
\hline & Jumlah & 1010 & 1075 & 1165 \\
\hline & Rata-rata & 72,14 & 76,79 & 83,21 \\
\hline & Pembulatan & 72 & 77 & \\
\hline
\end{tabular}

Berdasarkan dari table dan grafik diatas tingkat hasil belajar Geografi dari prasiklus masih terlihat rendah. Hal ini disebabkan penggunaan metode yang digunakan oleh guru monoton dan kurang bervarasi sehingga apa yang menjadi rumusan hipotesis penelitian ini didepan (Bab I) yaitu dengan Model Pembelajaran Picture And Picture dapat meningkatkan hasil belajar Geografi siswa kelas XI IIS 1 SMA Negeri I Koto Besar terbukti, hal ini ditandai dengan adanya peningkatan hasil belajar siswa mulai dari pra siklus sampai siklus II.

\section{Pembahasan}

Dari hasil penelitian di atas dapat dipahami bahwa penerapan model pembelajaran kooperatif tipe Picture And Picture dapat meningkatkan hasil belajar siswa. Hal ini sejalan dengan Sulfemi \& Minati (2018) yang menyatakan bahwa model Picture And Picture dapat meningkatkan kemampuan kognitif, afektif dan psikomotorik. Selanjutnya Prihatiningsih \& Setyanigtyas (2018) menyampaikan bahwa hasil belajar peserta didik mengalami peningkatan yang signifikan setelah penerapan model Picture And Picture.

Model pembelajaran kooperatif tipe Picture And Picture adalah suatu model pembelajaran dengan menggunakan gambar-gambar sebagai media dalam proses pembelajaran dimana gambar-gambar tersebut dipasangan ataupun diurutkan 
menjadi urutan yang logis, model pembelajaran kooperatif tipe picture and picture bertujuan untuk menarik perhatian siswa sehingga siswa dapat fokus dan dalam keadaan yang menyenangkan saat mengikuti pelajaran (Khalim \& Oktapian, 2020). Model Picture And Picture menggunakan media gambar untuk mempermudah guru, menjelaskan materi di depan kelas kepada siswa, guru menempelkan gambar dengan materi yang pelajari, guru memanggil salah satu siswa untuk maju ke depan dan menjelaskan dengan benar, guru menanyakan kepada siswa dasar pemikiran gambar tersebut (Gumay \& Ali, 2019).

Model pembelajaran Picture And Picture mampu memudahkan peserta didik dalam memahami materi, karena adanya tampilan visual. Siswa dapat secara intensif menganalisis materi hingga sampai pada pemahaman yang baik. Menurut Prihatiningsih \& Setyanigtyas (2018) model Picture And Picture mendorong siswa untuk terlibat aktif dalam pembelajaran dan meningkatkan kemampuan berpikir kritis. Model ini berorientasi pada pembelajaran aktif dan menyenangkan, yang dapat membantu siswa untuk berpikir logis dan sistematis (Gaffar, 2018).

Menurut Susanti \& Kusmariyani (2017) model pembelajaran Picture And Picture memiliki beberapa kelebihan yaitu: 1) Materi yang diajarkan lebih terarah karena pada awal pembelajaran guru menjelaskan kompetensi yang harus dicapai dan materi secara singkat terlebih dahulu. 2) Siswa lebih cepat menangkap materi ajar karena guru menunjukkan gambar-gambar mengenai materi yang dipelajari. 3) Dapat meningkat daya nalar atau daya pikir siswa karena siswa disuruh guru untuk menganalisa gambar yang ada. 4) Dapat meningkatkan tanggung jawab siswa, sebab guru menanyakan alasan siswa mengurutkan gambar. 5) Pembelajaran lebih berkesan, sebab siswa dapat mengamati langsung gambar yang telah dipersiapkan oleh guru. Kelebihan model ini adalah dapat meningkatkan cara berpikir terstruktur dan rasa tanggungjawab pada diri siswa yang ditunjukkan dengan penerimaan dan respon yang lebih cepat dari siswa berupa tanggapan terkait pertanyaan yang diajukan oleh guru (Yuniari, 2017).

\section{SIMPULAN}

Penerapan model pembelajaran Picture And Picture dapat tingkat hasil belajar siswa dalam belajar Geografi hal ini ditunjukkan dengan adanya peningkatan dari kondisi awal memiliki rata-rata 72 , Sementara itu pada siklus I 
diperoleh rata-rata 77 , dan pada siklus II terlihat naik rata-ratanya menjagi 83 . Adapun yang menjadi Saran dalam Penelitian Tindakan ini perlu dilakukan penelitian lanjutan untuk kelas yang sama atau berbeda dengan materi yang berbeda atau sama guna menghasilkan hasil yang lebih optimal. Selain itu juga perlu dilakukan pemantauan yang lebih banyak sehingga siswa mempunyai kesempatan untuk bertanya hal-hal yang tidak atau belum mereka mengerti selama proses pembelajaran berlangsung.

\section{DAFTAR RUJUKAN}

Ayuni, F. N. (2016). Pemahaman Guru Terhadap Pendekatan Saintifik (Scientific Approach) Dalam Pembelajaran Geografi. Jurnal Geografi Gea, 15(2), 1-7. https://doi.org/10.17509/gea.v15i2.3542

Emda, A. (2018). Kedudukan Motivasi Belajar Siswa Dalam Pembelajaran. Lantanida Journal, 5(2), 172. https://doi.org/10.22373/lj.v5i2.2838

Gaffar, A. A. (2018). Penerapan Model Pembelajaran Kooperatif Tipe Picture and Picture Untuk Meningkatkan Hasil Belajar Siswa Smp Pada Pembelajaran Ipa. Jurnal Bio Educatio, 3(1), 10-21.

Gumay, O. P. U., \& Ali, M. (2019). PENERAPAN MODEL PICTURE AND PICTURE PADA PEMBELAJARAN FISIKA KELAS VII SMP NEGERI PASENAN. SILAMPARI JURNAL PENDIDIKAN ILMU FISIKA, 1(1), 52-59. https://doi.org/https://doi.org/10.31540/sjpif.v1i1.312

Khalim, A. R., \& Oktapian, M. (2020). Pengaruh Penggunaan Model Pembelajaran Kooperatif Tipe Picture and Picture Terhadap Hasil Belajar Pendidikan Agama Islam. Akademika, 9(01), 109-126. https://doi.org/10.34005/akademika.v9i01.814

Kresnawati, N. (2013). Korelasi Kualitas Pembelajaran Geografi dan Hasil Belajar terhadap Sikap Peduli Lingkungan Siswa Kelas XII IPS SMAN 1 Ponorogo. Jurnal Inovasi Pendidikan IPA, I(September), 298-303. Retrieved from http://www.jurnal.unsyiah.ac.id/JAP/article/view/2568/2427

Prihatiningsih, E., \& Setyanigtyas, E. W. (2018). PENGARUH PENERAPAN MODEL PEMBELAJARAN PICTURE AND PICTURE DAN MODEL MAKE A MATCH TERHADAP HASIL BELAJAR SISWA. JPSd: Jurnal Pendidikan Sekolah Dasar, 4(1), 1-14. https://doi.org/http://dx.doi.org/10.30870/jpsd.v4i1.1441.g2353

Sulfemi, W. B., \& Minati, H. (2018). MENINGKATKAN HASIL BELAJAR PESERTA DIDIK KELAS 3 SD MENGGUNAKAN MODEL PICTURE AND PICTURE DANMEDIA. Jurnal Pendidikan Sekolah Dasar, 4(2), 228-242.

Susanti, P. A., \& Kusmariyani, N. N. (2017). PENERAPAN MODEL PICTURE AND 
100 | Jurnal Pendidikan dan Kewirausahaan Vol. 9 No. 12021

PICTURE BERBASIS PENDEKATAN SAINTIFIK UNTUK MENINGKATKAN HASIL PENGETAHUAN IPA. Jurnal Ilmiah Sekolah Dasar, 1(2), 99-106. Yuniari, I. G. A. B. (2017). PENERAPAN MODEL PICTURE AND PICTURE UNTUK MENINGKATKAN KEMAMPUAN MENULIS PUISI PADA SISWA KELAS X MIA 6 SMA NEGERI 1 MENGWI TAHUN PELAJARAN 2016 / 2017. E-Journal Jurusan Pendidikan Bahasa Dan Sastra Indonesia, 7(2), 1-11. https://doi.org/http://dx.doi.org/10.23887/jjpbs.v7i2.12407 